\title{
Opinions of Classroom Teachers' about the Vocabulary Teaching in Turkish Course*
}

\author{
Hüseyin ANILAN ${ }^{\dagger a}$, Berrin GENÇ ERSOY ${ }^{b}$ \\ a Eskişehir Osmangazi University, Faculty of Education, Eskişehir/Turkey \\ ${ }^{b}$ Ministry of Education, Mehmet Avdan Primary Scholl, Eskişehir/Turkey
}

\section{Article Info}

DOI: $10.14527 /$ pegegog.2014.018

Article history:

Received 22 February 2014

Revised 29 May 2014

Accepted 11 July 2014

Keywords:

Turkish instruction,

Vocabulary teaching,

Classroom teachers' views.

\begin{abstract}
The purpose of this study is to determine classroom teachers' views on applications regarding vocabulary teaching in Turkish Course. In this regard, a qualitative research design was implemented and, the participants of the study were twenty primary school teachers. The qualitative data were gathered through constructed written interview form including open ended questions, and the researchers aimed to investigate teachers' views on applications regarding vocabulary teaching and also immediate concerns encountered during this practicum The findings of the thematic analysis highlighted some sub-themes and concepts, and the following main themes: Explanations and applications regarding the curriculum, the sufficiency of textprocessing steps, methods and techniques and the use of resources of the course, mass media and the effects of environmental and familial factors. The results of the study show that the teachers have different views on the explanations and applications regarding the curriculum, do not have exact information about number of the acquisitions related to vocabulary teaching in Turkish curriculum, have different views on the quality of the activities appearing in the text-processing steps, think that it is helpful to practice on the keywords for students' vocabularies, use specific vocabulary teaching methods and techniques and from time to time have problems regarding making students develop an understanding of newly-learnt words.
\end{abstract}

\section{Introduction}

Individuals can develop themselves in many ways an important tool for the smallest element of the language are words. Individuals' concepts as symbols with words, thinkers and most basic requirements of the most complex emotions everything through words transmit and they transferred statements again words by meaning (Yalçın \& Özek, 2006).

Individuals have the vocabulary they are developing formal and informal ways. In other words, word learning is an ongoing process throughout a person's life. In this context, the importance of vocabulary teaching conducted in a formal manner is undeniable. Indeed, planned, scheduled and carried out in a systematic way of teaching the word positively affects students' academic lives.

In schools planned and scheduled in a manner realized the word education to work in all subjects are featured although vocabulary development, vocabulary teaching activities like Turkish first aim of the course located within and above mentioned activities in their textbooks, the text is done through. Turkish lessons' texts realized through word of teaching, learning and teaching process, under the title "Key words working", "meaning of unknown words to work with" and "Vocabulary development" under the heading area with activities are carried out. All this activity planning, implementation and evaluation

\footnotetext{
* This study is a developed version of a presentation presented at 11. National Classroom Teacher Symposium which is held by Recep Tayyip Erdoğan University on May 24-26, 2012

Corresponding author: anilan.huseyin@gmail.com
} 
of important roles and responsibilities in the process of classroom teachers are loaded. In the process of teaching practices and teachers' words regarding the situation to determine the opinions, the word education is essential for the smooth running and more qualified. Therefore, in this study the word Turkish lessons teachers' opinions regarding teaching practices, problems and solutions of these problems related to the evaluation of teachers is intended.

\section{Method}

\section{Research Design}

Events of the people surveyed, cases, norms and values related perspectives, thoughts and feelings from the general characteristics of qualitative research that learning is expressed (Yıldııım \& Şimşek, 2006). Indeed, Neuman (2010) qualitative study examined people's perspective begins with that and then examined human world how you see the situation, describe how you or the situation happen to them mean that allows finding indicates that. In this context, qualitative research approach was adopted in this study and those made in the course of classroom teachers Turkish word for teaching practices aimed to determine their views of what is happening.

\section{Participants}

The participants were connected to the Ministry of Education who work in primary schools has created 20 classroom teachers. In the selection of participants, all working in public schools and one to five classes. Turkish lessons by observing classes have been in existence, within the criterion sampling and purposive sampling method was adopted. Participants' identities were kept confidential at all stages of research.

\section{Instrument}

The research data collection tool, as stipulated by Turkish curriculum prepared by the researchers including the step is written structured interview form. Interview questions form the Turkish curriculum components were taken into consideration. After the interview form prepared in the form of three experts in the field of language and expression, the three experts in the field have been studied in terms of scope. According to the evaluation made the necessary corrections have been made and given final shape jerseys have been implemented.

\section{Data Collection}

The formulation of interview questions related to teaching literature scanned words and forms that are created within the scope of expert opinions have been implemented after evaluation. 20 classroom teachers have been included in the study. Covered by the study of classroom teachers volunteered to participate in the study. Eight interview questions to teachers via e-mail or submitted in writing through individual interviews and were asked to answer interview questions.

\section{Data Analysis}

In the analysis of the data collected using interview forms were carried out with thematic analysis techniques. Thematic priorities under analysis structured interview form with all the opinions received in writing, was made into a single text. Two researchers separately in the process of ongoing thematic coding analysis of the opinions of the participants in order to create themes were grouped items, grouped candidates themes of these items were obtained and the opinions settles to the bottom of 
these themes re-examined. Thus, sub-themes and concepts, has been solved by combining the themes that will be associated with. For a better understanding of the thematic analysis, has been quoted directly from the words of the participants. Validity of the data for coding, whether the purpose of the analysis were presented to expert opinion; thematic coding has been restated in accordance with the opinion. Research for reliability, Stemler (2001) measurement reliability are taken into consideration. In this study the percentage of the consensus of the two encoders are used for reliability. Accordingly, $90 \%$ increased reliability and measurement is considered reliable.

\section{Results}

Turkish word contained within the curriculum teachers' opinions on the process of teaching aimed at determining the scope of this research related to teaching the word of the teacher as a result of opinion was reached on the following themes:

\section{Description of programs and applications}

Based on feedback received from teachers involved in the program description and application are the main theme has emerged. Teachers, Turkish curriculum are of the opinion that the increase of the teacher-student interaction. Classroom teachers teaching the word of Turkish curriculum is improved in terms and words that serve education stated. However, some teachers in terms of teaching the word of the program highlighting the lack of explanation and example applications perform random words stated that teaching. In addition, research findings related to teaching the word of teachers emphasized the large number of gains seen that.

\section{Adequacy of text processing steps}

Teachers' text processing steps, some of the activities in the nature of words while appropriate and sufficient for teaching a portion of the teachers in the development of the vocabulary of the events are of the opinion that insufficient. Teachers also on the level of activity in the words of the students stated that. In general text processing steps that are of the opinion that the word is functional in teaching, teachers place more emphasis on the use of technology in applications that need to be emphasized. Class of the learning environment of the physical conditions of the time, and the active participation of students in the implementation of text processing steps, indicating that effective teachers; words spoken or written or by way of expression embodied and expressed by students can be induced internalization. In addition, some of the teachers of grammar in text processing steps efficacy and effectiveness are insufficient weight given to the opinion that unless stated.

\section{Methods and techniques}

Turkish lesson teachers to teach the process of learning words for teaching as closely as far based on the principle that they move, many sensory organs unless you floor that, newly learned words in everyday life associated order to ensure that applications that they mentioned and the process with other courses attempted to relate stated that. New words for students to be engaged by the activities associated with the new words that they mentioned other new words and words used in the sentence again stated that the structures. Words indicating that they experienced to overcome this problem and difficulties in teaching teachers from time to time, it is often stated that they receive support from their colleagues. Teachers also declared that give place to the word education in the process of question and answer, discussion, games, association, case study, research, presentation, dramatization, concept maps, $5 \mathrm{~N} 1 \mathrm{~K}$, story creation, puzzles, do not hint, hint, description, brainstorming, trial and error, learning by doing, examples, such as the methods and techniques. 


\section{The use of teaching resources}

Teacher of the dictionary, spelling guide, idioms and proverbs dictionary, word images, reference books, short stories, word cards, students have the story books, student workbooks, textbooks, texts, three-dimensional materials, such as materials words useful in teaching that agree It is understood that. Teachers also used effectively in the teaching of words in textbooks for the nature of the texts are of the opinion that there are problems.

\section{Mass media}

In the interviews, teachers teaching the word that happen only in the classroom, students learn new words from mass media also stated that. Positive and negative effects of mass media Referring to the teachers, students exposed to more stimuli, stating that they are more successful in the use of the word in question should be used in place of stimuli and emphasized that true. Mass media is one of the negative effects of television on the mention of the word education teachers, television programs and contribute to meaningful learning of the words stating that bringing the educational qualifications of television programs which stated that the word is more effective in teaching.

\section{Environment and family influence}

Not limited to students of their surroundings, indicating that restrict learning new words, teachers of students in different environments have advocated the view that enriches learning new words. Teachers, students and their families to express themselves in the position they thought that the hazard is very important. Teachers of students in the vicinity of the vocabulary of people to have a direct impact on the education of students stated that word. In addition, students in the immediate vicinity of the person stating that the model teachers, students of all persons in the immediate vicinity to be sensitive to this issue would be useful in terms of the students are of the opinion.

\section{Conclusion, Discussion \& Implementation}

Turkish word contained within the curriculum and teaching process in order to determine the views of the teachers in this study, Turkish teachers' curriculum focuses on teaching the word of the adequacy of description and application is seen to have different opinions. Teachers in the teaching of the word, in its teaching-learning process are specific to different applications to perform. This result Karadüz and Yıldırım (2011) is in accord with the results of research.

Another of the results obtained in the curriculum of Turkish teachers' word that large numbers of gains related to teaching are their opinions. In this context, the number of Turkish words gain related to teaching in the curriculum other gains compared with the number of words related to teaching an acquisition, very few can be mentioned. Therefore, teachers gain more than the number of words that related to teaching Turkish curriculum for the opinions contained in gains related to teaching words to have information on the number they can be interpreted.

Teachers some of the text processing step the activities in the nature of words for teaching proper and adequate while teachers some of the events mentioned assets in the development is insufficient and the activities carried out in and read the text of words in the students' level is above perceive. These results obtained Karadüz and Yıldırım (2011) research shows similarity with the results. Similarly Bilgen (1996) in a survey conducted by some of the words that should not be included in textbooks, which should be considered if the words are said to produce (Cite in: Karatay, 2007).

Teachers work with keywords will contribute to the development of the students are of the opinion vocabulary. In addition, teachers text processing steps carried out in practice in the choice of words in 
the students only know the meaning of words that do not include a vocabulary to contribute to that, besides the meaning of known words also in daily life effectively required for the practice time you need to consider that. Similarly Başdamar (2010) the activities carried out in Turkish textbooks in developing students' vocabulary development of adequate and effective vocabulary for specifying whether or not a dedicated course of time there are suggestions that it is necessary.

Teachers, students learn new words in order to ensure internalized by those words should be formalized through written and oral expression are of the opinion. In addition, teachers in the teaching of the word of methods and techniques specific to their learning-teaching process, they gave place to be seen. Teachers also learned new words everyday life and practices can be associated with other courses that give place to be seen. Teachers stated that they held these practices will help word permanent learning in teaching (Gürses, 2003).

Teachers in the teaching process words, new words to be associated with the other new words in sentences and repetition of words such as making are to give place to practice. In fact, frequent use of newly learned words and cannot be grasped as underlining the dictionary meaning of words to read the written word are methods that can be applied in learning (Ruşen, 1999).

Teachers Turkish lesson vocabulary teaching in the process of question and answer, discussion, games, association, case study, research, presentation, dramatization, concept maps, 5N1K, story creation, puzzles, giving tips, stalking, description, brainstorming, trial and error, learning by doing , reward, such as methods and techniques they use to embody seen. Because words are intended to teach students how different events and also comprehend that if the learning will be permanent (Gürdal and Arslan, 2011, p. 36). Rock and Maker (2007) in language teaching, games and puzzles make the lessons more interesting and fun is that. Similarly, Çeçen (2007) and Gürdal and Arslan (2011) to improve students' vocabulary word games, puzzles, riddles and so on. Stressed the importance of benefiting from activities involving.

Teacher of the words in teaching dictionary, spelling guide, idioms and proverbs dictionary, word images, reference books, short stories, word cards, students have the story books, student workbooks, textbooks, texts, three-dimensional materials, such as materials to be useful, they argue. Indeed, some research in the teaching of the word of dictionary it is important to emphasize that benefit (Çeçen, 2007; Göçer, 2009; Karatay, 2007; Gürses, 2003). However, the materials to be used in teaching the word of teachers of students who have the habit of using these materials are not available, and sometimes he cannot use the tools criticisms are correct and appropriate.

Teachers in the process of learning new words from time to time and to overcome their distress is often seen that receive support from their colleagues. These results Karadüz and Yıldırım (2011) is in accord with the results of research. Indeed Karadüz and Yıldırım (2011) of teachers in the teaching of the word; students, from the structure of words, the environment and lack of resources, difficulties and problems arising from the experiences were detected.

In order to develop students' higher order thinking skills that you need to have rich vocabulary minded teachers, in order to enrich the vocabulary of students, teachers, students and parents believe that cooperation is crucial.

Teachers in the teaching process words technological feasibility of having hardware learning environment and the large number of material conditions to work effectively are of the opinion that it is important in terms of vocabulary teaching. Indeed Kolich (1991) (Cite in: Baturay, Yıldırım \& Daloğlu, 2007) A survey conducted in the students' computers word learning is quite enjoyable and efficient they found revealed, but that technology alone is not used teacher-controlled activities should be supported by argued that. Similarly Karatay (2007), in the light of technological developments, students learn vocabulary development work can also make fun stated.

Teachers of the mass media have referred to the positive and negative effects on word learning. In addition, students in the teaching of the word of their surroundings and family are of the opinion that it 
is effective. Demir (2007) children's vocabulary development and enrichment is thought to be due to the family's aid.

In accordance with the results obtained can be improved following recommendations:

- This research can be carried out like a larger study group.

- Words used in teaching on the nature of the text and text activities should be conducted.

- If the effectiveness of teaching and teaching new words in the text rather than only the consolidation of previously learned words or use should be given to activities.

- Word-to-date technology in teaching should be used as functional.

- Students 'ability to develop vocabulary teacher-student and parents' cooperation should be taken into account. 


\title{
Türkçe Dersinde Gerçekleştirilen Sözcük Öğretimine ïlişkin Sınıf Öğretmenlerinin Görüşleri ${ }^{*}$
}

\author{
Hüseyin ANILAN ${ }^{\dagger a}$, Berrin GENÇ-ERSOY ${ }^{b}$ \\ ${ }^{a}$ Eskişehir Osmangazi Üniversitesi, Eğitim Fakültesi, Eskişehir/Türkiye \\ ${ }^{b}$ Milli Eğitim Bakanlığı, Mehmet Avdan İlkokulu, Eskişehir/Türkiye
}

\section{Makale Bilgisi}

DOI: $10.14527 /$ pegegog.2014.018

Makale Geçmişi:

Geliş 22 Şubat 2014

Düzeltme 29 Mayıs 2014

Kabul $\quad 01$ Temmuz 2014

Anahtar Kelimeler

Türkçe Öğretimi,

Sözcük öğretimi,

Sınıf öğretmeni görüşleri.

\section{Öz}

Bu çalışmanın amacı sınıf öğretmenlerinin Türkçe derslerinde gerçekleştirilen sözcük öğretimi uygulamalarına ilişkin görüşlerini belirlemektir. Bu bağlamda araştırmada nitel araştırma deseni benimsenmiştir. Araştırmanın katılımcılarını ilkokullarda görev yapmakta olan 20 sınıf öğretmeni oluşturmuştur. Araştırmacılar tarafından öğretmenlerin sözcük öğretimi uygulamalarına ilişkin görüşleri ve süreç içerisinde karşılaştıkları sorunları ile çözüm önerilerini belirlemeyi amaçlayan açık uçlu sorulardan oluşan yapılandırılmış yazılı görüşme formu yoluyla toplanan veriler, tematik analiz tekniğiyle çözümlenmiştir. Öğretmen görüşlerinin, programda yer alan açıklamalar ve uygulamalar, metin işleme basamaklarının yeterliliği, yöntem ve teknikler, ders kaynaklarının kullanımı, kitle iletişim araçları ve çevre-aile etkisi temalarında toplandığı görülmüştür. Araştırma sonucunda öğretmenlerin; sözcük öğretimine yönelik açıklama ve uygulamalarının yeterliliğine ilişkin farklı görüşlere sahip oldukları; Türkçe öğretim programının sözcük öğretimiyle ilgili kazanımları konusunda yeterli bilgi sahibi olmadıkları; metin işleme basamaklarında yer alan etkinliklerin niteliğine yönelik farklı görüşlerinin olduğu; anahtar sözcüklerle çalışmanın öğrencilerin sözcük dağarcığı gelişimine katkı sağlayacağını düşündükleri; sözcük öğretiminde farklı yöntem ve tekniklere başvurdukları ve yeni sözcüklerin öğrencilere kavratılması sürecinde zaman zaman sıkıntı yaşadıkları görülmektedir.

\section{Giriş}

Bireylerin kendilerini birçok yönden geliştirebilmeleri için önemli bir araç olan dilin en küçük unsuru sözcüklerdir. Bireyler kavramların sembolleri olan sözcüklerle düşünürler ve en basit gereksinimlerinden en karmaşık duygularına kadar her şeyi sözcükler aracılığıyla aktarırlar ve bu yolla aktarılan ifadeleri de yine sözcükler yoluyla anlamlandırırlar (Yalçın ve Özek, 2006). Bir başka deyişle bireyler düşüncelerini, bildiklerini sahip oldukları söz varlığı oranında aktarabilmektedirler. Nitekim sözcükler olmadan düşüncelerin aktarılması veya tam anlamıyla ifade edilmesi olanaksızdır (Ağca, 1999; Akarsu, 1998; Yalçın, 2005). Bu nedenle bir birey ne kadar çok sözcük bilirse düşünme ve düşüncelerini aktarabilme yetisi de o kadar gelişmiş olacaktır.

Bireyler sahip oldukları söz varlığını formal (planlı, programlı, resmi) ve informal (tesadüfi, gayriresmi) yollarla geliştirmektedirler. Bu bağlamda söz varlığı oluşturma sürecinin formal boyutunu bireylerin okul yaşantısı oluştururken, informal boyutunu ise okul dışı yaşamının oluşturduğu söylenebilir. Bir başka deyişle sözcük öğrenme kişinin yaşamı boyunca devam eden bir süreçtir. Bu bağlamda da formal bir şekilde gerçekleştirilen sözcük öğretiminin önemi yadsınamaz. Nitekim planlı, programlı ve sistemli bir şekilde gerçekleştirilen sözcük öğretimi öğrencilerin akademik yaşantılarını olumlu yönde etkiler. Aksi

\footnotetext{
* Bu çalışma 24-26 Mayıs 2012 tarihleri arasında Recep Tayyip Erdoğan Üniversitesi’nin düzenlediği “11. Ulusal Sınıf Öğretmenliği Sempozyumu"nda sunulan sözlü bildirinin geliştirilmiş halidir.

† Yazar: anilan.huseyin@gmail.com
} 
takdirde söz varlığını yaşının gerektirdiği ölçüde geliştirememiş bir öğrencinin, derslerin konularına ilgi duyabilmesi, öğretmenlerin sınıfta anlattıklarını ve ders kitaplarında okuduklarını anlayabilmesi, anladıklarını anlatabilmesi, dolayısıyla derslerde başarılı olabilmesi imkânsızdır (Çeçen, 2002, s.8). Bu nedenle gerçekleştirilecek sözcük öğretiminin planlı, programlı ve sistemli bir şekilde olması gerekmektedir. Göçer (2009), sözcük öğretiminin ilköğretimin ilk yılından itibaren başlayarak amaçlı ve sistemli bir şekilde yapılması gerektiğini belirtmektedir.

Okullarda planlı ve programlı bir biçimde gerçekleştirilen sözcük öğretimi çalışmalarına tüm derslerde yer veriliyor olmasına rağmen söz varlığını geliştirme, sözcük öğretimi gibi etkinlikler öncelikle Türkçe dersinin amaçları içinde yer almaktadır. Ana dili dersi olan Türkçe derslerinde (Demirel, 2006) söz dağarcığının geliştirilmesi için gerçekleştirilen sözcük çalışmaları oldukça önemlidir (Göğüş, 1983). Türkçe öğretim programının genel amaçlarına bakıldığında da öğrencilerin; "metinler arası düşünme becerilerini geliştirerek söz varlığını zenginleştirmek" ifadesi yer almaktadır (MEB, 2009). Genel amaçların yanı sıra "söz varlığını geliştirme" alt başlığıyla "okuma" öğrenme alanında söz varlığını geliştirmeye yönelik kazanımlar da bulunmaktadır. Ayrıca Türkçe dersinin diğer amaçları da dikkate alındığında öğrencilerin belirtilen amaçlara ulaşabilmelerinde ve dil becerilerini geliştirebilmelerinde zengin bir söz varlı̆ı̆na sahip olmaları gerektiği açıktır.

Öğrencilerin zengin bir söz varlı̆̆ına sahip olabilmeleri Türkçe derslerinde gerçekleştirilen sözcük öğretiminin sistemli bir şekilde yapılmasına bağlıdır. Nitekim sözcük öğretimi "yalnızca sözlüğe bakarak oradan kelimelerin anlamlarını alıp yeni cümleler oluşturma çabası değil, sözcüklerin taşıdığı anlamları içselleştirme işidir. Sözcük öğrenme süreci karmaşık bir alan olarak, kavramlar arasında ilişkiler kurmaya, kavramların organize edilmesine ve sözcükler hakkındaki bilgilerin geliştirilip düzenlenmesine dayanır." (Calp, 2010, s.260; Beck ve McKeown'den, 1991, s.74). Bu da sözcük öğretiminin yapılış biçimiyle doğrudan ilgilidir. Bu nedenle bireylerde söz varlığının gelişimi için sözcük öğretiminin nasıl yapıldığı önemlidir (Paul, 1996, s.3).

Amaca ve duruma uygun, kalıcı, hızlı bulunabilen, uygun yere eklenebilecek ve kurallara uygun kullanılabilecek sözcük dağarcığı edinmeyi amaçlayan sözcük öğretimi (Löschmann, 1993'den Akt: Kaptı, 2008), eğitim ve öğretimde kullanılacak araç-gerecin iyi tasarlanarak hazırlanması ile mümkündür (Karatay, 2007). Bilindiği üzere Türkçe derslerinde söz varlığını geliştirmeye yönelik etkinlikler ders kitapları aracılığıyla gerçekleştirilmektedir. Ders kitapları temel bir bilgi kaynağı olup derslerde en çok kullanılan materyallerden biridir (Kaya, 2002, s.92-93; Kılıç ve Seven, 2002, s.26). Bu nedenle ders kitaplarının kaynaklık ettiği söz varlığı öğretiminin içgüdüsel, kendiliğinden ve rastlantısal olarak değil sistemli bir şekilde yapılması ve şansa bırakılmaması gerekmektedir (Hameau, 1988, ss.301-305). Ders kitaplarında yer alan metinler ise sözcük öğretiminin ana materyalleridir. Bir başka deyişle öğrencilerin okuldaki sözcük bilgilerinin temel kaynağını metinler oluşturmaktadır (Cunningham ve Stanowich, 1998). Ders kitaplarındaki metinler sayesinde, söz varlı̆ının zenginleştirilmesi, okuma, metnin dilinin, anlatımının ve türünün incelenmesi sağlanmaktadır (Sağır, 2002). Bu bağlamda metinlerin öğrencilerin söz varlığı gelişimine katkısı büyüktür. Bu nedenle Türkçe derslerinde kullanılacak olan metinlerin nitelikli olarak hazırlanması gerekmektedir (Aytaş, 2001).

Bir metnin sözcük öğretimi açısından nitelikli olması; sözcük bakımından zengin, öğrenci yaş ve gelişim özellikleri gözetilerek, çevre koşulları, sosyal ve kültürel yaşamları dikkate alınarak, öğrencilerin ilgi ve beklentilerine uygun hazırlanması şeklinde açıklanabilir. Nitekim Güneş (2002) benzer şekilde ders kitaplarındaki metinlerin seçiminde öğrencilerin gelişim özellikleri, yaşları, yerel ağız gibi, dil gelişimini etkileyen unsurlar ile yaşadıkları çevre ve sosyo- ekonomik koşulların göz önünde bulundurulması gerektiğini vurgulamaktadır. Söz konusu metinler yoluyla gerçekleştirilen sözcük öğretimi etkinliklerinin ise sayıca yeterli olması sözcük öğretiminin bir diğer önemli boyutudur. Nitekim "Sözcük öğretimi çalışmalarında ne kadar çok etkinlikten, alıştırmadan yararlanılırsa, öğrenilen sözcükler o kadar kalıcı olur, hafızaya yerleşir. Öğrencide ancak bu yolla daha kalıcı bir sözcük dağarcığı oluşturulabilir." (Pehlivan, 2008). 
Türkçe derslerinde metinler aracllı̆̆ ile gerçekleştirilen sözcük öğretimi, öğrenme öğretme süreci başı̆ıı altında, hazırlık aşamasının "Anahtar kelimelerle çalışma" ve anlama aşamasının "Anlamı bilinmeyen kelimelerle çalışma" ve "Söz varlığını geliştirme" başıkları altında yer alan etkinliklerle gerçekleştirilmektedir. Anahtar kelimelerle çalışma etkinlikleri metin içerisinde verilen ve öğrencilerin metni anlamlandırmalarını sağlayan sözcükleri öğrenmelerine yönelik çalışmaları kapsamaktadır. Anlamı bilinmeyen kelimelerle çalışma bölümünde ise okuma sırasında öğrenciler tarafından saptanan ve anlamı bilinmeyen sözcüklerin anlamları üzerinde durulmaktadır. Söz varlığını geliştirme etkinliklerinde, öğrencilerin bildikleri sözcüklerden yola çıkarak anlamı bilinmeyen sözcüklerin anlamlarına ulaşmaları ve dağarcıklarına yerleştirmeleri amaçlanmaktadır. Ayrıca söz varlı̆ını kullanmada öğrencilerin öğrendikleri sözcükleri kendi tercih ettikleri yollar ile (yazılı, sözlü ya da görsel sunum) kullanmaları, sözcükleri yerinde ve anlamına uygun olarak kullanmaları gibi etkinliklere yer verilmektedir. Tüm bu etkinliklerin planlanması, uygulaması ve değerlendirilmesi sürecinde sınıf öğretmenleri önemli görev ve sorumluluklar yüklenmektedirler. Öğretmenlerin sözcük öğretimi sürecindeki uygulamalara ve yaşananlara ilişkin görüşlerinin belirlenmesi, sözcük öğretiminin daha nitelikli ve sorunsuz yürütülebilmesi için önemlidir. Bu nedenle bu çalışmada Türkçe dersi sözcük öğretimi uygulamalarına ilişkin öğretmen görüşleri, karşılaşılan sorunlar ve bu sorunların çözümüne ilişkin öğretmen görüşlerinin değerlendirilmesi amaçlanmıştır.

\section{Yöntem}

\section{Araştırma Modeli}

Araştırma yapılan kişilerin olay, olgu, norm ve değerler ile ilgili bakış açılarını, duygu ve düşüncelerini öğrenme nitel araştırmanın genel özelliklerindendir (Yıldırım ve Şimşek, 2006). Nitekim Neuman (2010) da nitel araştırmanın incelenen insanların bakış açılarıyla başladığını ve sonra incelenen insanların dünyayı nasıl gördüğünü, durumu nasıl tanımladığını veya durumun onlara ne anlam ifade ettiğini bulmayı sağladığını ifade etmektedir. Bu bağlamda bu araştırmada da nitel araştırma yaklaşımı benimsenmiş olup sınıf öğretmenlerinin Türkçe derslerinde gerçekleştirdikleri sözcük öğretimi uygulamalarına yönelik görüşlerinin neler olduğunun belirlenmesi amaçlanmıştır.

\section{Katılımcılar}

Araştırmanın katııımılarını Milli Eğitim Bakanlığı'na bağlı ilköğretim okullarında görev yapmakta olan 20 sınıf öğretmeni oluşturmuştur. Katılımcıların seçiminde, tümünün devlet okullarında çalışıyor ve 1-5. sınıflar Türkçe derslerini yürütüyor olmaları gözetilerek, amaçlı örnekleme yöntemi dahilinde ölçüt örnekleme benimsenmiştir. Katılımcıların kimlikleri araştırmanın bütün aşamalarında gizli tutulmuş ve Tablo 1'de de görüldüğü gibi öğretmenler harflerle kodlanmıştır. Nitel araştırmalar çalışma grubunu oluşturan katılımcıları ayrıntılı olarak betimlemeyi gerektirdiğinden (Cresswell, 2012), araştırmaya katılan öğretmenlerin özellikleri Tablo 1'de sunulmuştur.

Tablo 1'de görüldüğü gibi harflendirmesi yapılan katılımcıların profilinde kadın öğretmenlerin çoğunlukta olduğu ( $f=14)$, meslekteki kıdemler 1 ile 11 yıl arasında dağılıma sahip olup bunlar içerisinde 5 yıl ve daha az kıdemli olanların çoğunlukta olduğu, çalışma grubunun çoğunluğunun ilçe merkezinde görev yaptığı ve okutulan sınıf düzeylerinin dağılımında ise birbirine yakın değerler olduğu görülmektedir. 
Tablo 1.

Katılımcıların Özellikleri.

\begin{tabular}{|c|c|c|c|c|}
\hline Katılımcı & Cinsiyet & Kidem (Yıl) & Çalışılan Yer & Okuttuğu Sınıf Düzeyi \\
\hline Öğretmen A & Kadın & 1 & illçe & 5 \\
\hline Öğretmen B & Erkek & 10 & İlçe & 5 \\
\hline Öğretmen C & Erkek & 10 & İlçe & 1 \\
\hline Öğretmen D & Erkek & 3 & Köy & 1 \\
\hline Öğretmen $\mathrm{E}$ & Erkek & 5 & İlçe & 2 \\
\hline Öğretmen F & Kadın & 3 & illçe & 4 \\
\hline Öğretmen G & Kadın & 3 & İlçe & 2 \\
\hline Öğretmen H & Kadın & 1 & Köy & 3 \\
\hline Öğretmen I & Kadın & 7 & İlçe & 1 \\
\hline Öğretmen J & Kadın & 3 & İlçe & 2 \\
\hline Öğretmen $\mathrm{K}$ & Kadın & 5 & Köy & 5 \\
\hline Öğretmen L & Kadın & 11 & İlçe & 3 \\
\hline Öğretmen M & Kadın & 3 & İlçe & 4 \\
\hline Öğretmen N & Kadın & 5 & ìlçe & 1 \\
\hline Öğretmen O & Kadın & 10 & illçe & 3 \\
\hline Öğretmen P & Kadın & 3 & İlçe & 2 \\
\hline Öğretmen R & Erkek & 3 & Köy & 4 \\
\hline Öğretmen S & Kadın & 3 & İlçe & 5 \\
\hline Öğretmen T & Kadın & 5 & Belde & 2 \\
\hline Öğretmen U & Erkek & 5 & İlçe & 3 \\
\hline
\end{tabular}

\section{Veri Toplama Aracı}

Araştırmanın veri toplama aracı, Türkçe öğretim programının öngördüğü aşamaları içeren ve araştırmacılar tarafından hazırlanan yapılandırılmış yazılı görüşme formudur. Görüşme formunda yer alan sorular Türkçe öğretim programı bileşenleri dikkate alınarak hazırlanmıştır. Görüşme formu hazırlandıktan sonra formu üç alan uzmanı dil ve anlatım, üç alan uzmanı ise kapsam bakımından incelenmiştir. Yapılan değerlendirmelere göre gerekli düzeltmeler yapılmış ve forma son şekli verilerek uygulamaya geçirilmiştir.

\section{Verilerin Toplanması}

Araştırma verileri 2011-2012 öğretim yılında toplanmış ve araştırmanın gerçekleştirilmesinde aşağıdaki aşamalar izlenmiştir:

- Görüşme soruları oluşturulurken öncelikle sözcük öğretimine ilişkin alan yazın taranmış ve oluşturulan form uzman görüşleri kapsamında değerlendirildikten sonra uygulamaya sokulmuştur.

- Çalışma kapsamına 20 sınıf öğretmeni alınmıştır.

- Çalışma kapsamına alınan sınıf öğretmenleri çalışmaya katılma konusunda gönüllü olmuşlardır. Sınıf öğretmenlerine 8 görüşme sorusu mail aracılığıyla ya da birebir görüşmeler yoluyla yazılı olarak sunulmuş ve görüşme sorularını cevaplamaları istenmiştir.

- 20 sınıf öğretmeni tarafından doldurulan formlar bizzat araştırmacılardan birisi olan uygulayıcı öğretmen tarafından toplanmıştır. 


\section{Verilerin Analizi}

Görüşme formu kullanılarak toplanan verilerin analizinde tematik analiz tekniği işe koşulmuştur. Tematik analizde veriler içinde tema ve örüntüler aramak için analitik tekniklere odaklanılır. Bu analiz yönteminin en önemli özelliklerinden biri verilerin kodlanmasıdır. Verilerin kodlanmasıyla aynı biçimde kodlanmış tüm veriler okunur ve o kodun özünde ne olduğu bulunmaya çalışılır. Daha sonra farklı bir durum için aynı biçimde kodlanmış verilere bakılabilir ve diğer etkenlere bağlı olarak nasıl değiştiği ya da çeşitlendiği görülebilir (Ersoy ve Yalçınoğlu, 2012). Tematik analiz kapsamında öncelikle yapılandırılmış görüşme formu ile yazılı olarak alınan bütün görüşler, tek bir metin haline getirilmiştir. Devam eden çözümleme sürecinde iki araştırmacı ayrı ayrı tematik kodlama amacıyla katılımcıların görüşlerinden tema oluşturmak için ögeleri gruplamış, gruplanmış bu ögelerden aday temalar elde edilmiş ve bu temaların altına yerleşen görüşler tekrar incelemiştir. Böylelikle alt temalar ve kavramlar, temalarla ilişkili olacak şekilde birleştirilerek çözümlenmiştir. Yapılan tematik çözümlemenin daha iyi anlaşılması için, katılımcıların ifadelerinden doğrudan alıntılar yapılmıştır. Bu yolla geçerlik ve inandırıcılığın sağlanması (Wolcott, 1990) amaçlanmıştır. Verilerin kodlama geçerliği için, yapılan çözümlemenin amaca uygun olup olmadığı uzman görüşüne sunulmuş; gelen görüşler doğrultusunda tematik kodlama yeniden düzenlenmiştir.

Araştırma güvenirliği için Stemler'in (2001) ölçüm güvenirliği dikkate alınmıştır. Buna göre kodlayıcı ya da kodlayıcılar arasındaki uyum yüzdesinin yüksek olması, ölçüm güvenirliğinin yüksek olduğunu göstermektedir (Stemler, 2001). Bu araştırmada da iki kodlayıcının görüş birliği yüzdesi güvenirliği kullanılmıştır. Bunun için Miles ve Huberman'ın (1994) $P$ (Uzlaşma yüzdesi)=Na(Görüş Birliği)/Na(Görüş Birliği)+Nd(Görüş Ayrılığı)x100 güvenirlik formülü kullanılmıştır. Buna göre güvenirlik \%90 çıkmış ve ölçüm güvenilir kabul edilmiştir.

\section{Bulgular}

Türkçe öğretim programı içerisinde yer alan sözcük öğretimi sürecine ilişkin öğretmen görüşlerini belirlemeyi amaçlayan bu araştırma kapsamında sözcük öğretimine ilişkin alınan öğretmen görüşleri sonucunda aşağıdaki temalara ulaşılmıştır:

- Programda yer alan açıklamalar ve uygulamalar.

- Metin işleme basamaklarının yeterliliği.

- Yöntem ve teknikler.

- Ders kaynaklarının kullanımı.

- Kitle iletişim araçları.

- Çevre- aile etkisi.

\section{Programda Yer Alan Açıklamalar ve Uygulamalar}

Öğretmenlerden alınan görüşler doğrultusunda programda yer alan açıklamalar ve uygulamalar ana teması ortaya çıkmıştır. Söz konusu ana temanın alt temaları ve kavramları Şekil 1'de verilmiştir.

Sınıf öğretmenlerinin Türkçe öğretim programında yer alan açıklama ve uygulamalara ilişkin görüşleri Şekil 1'de verilmektedir. Buna göre öğretmenler, Türkçe öğretim programının öğretmen-öğrenci etkileşimini arttırdığı görüşündedirler. Sınıf öğretmenleri Türkçe öğretim programının sözcük öğretimi açısından geliştirilebilir olduğu düşüncesindedirler. Aynı zamanda öğretmenler Türkçe öğretim programının sözcük öğretimine hizmet ettiğini belirtmişlerdir. Ancak kimi öğretmenler ise yukarıda belirtilen görüşün aksine sözcük öğretimi açısından programın açıklamalarının ve örnek uygulamalarının yetersizliğini vurgulayarak gelişigüzel sözcük öğretimi gerçekleştirdiklerini belirtmişlerdir. Ayrıca araştırma bulgularında öğretmenlerin sözcük öğretimine ilişkin kazanımların sayısına da vurgu yaptıkları görülmektedir. Örneğin Öğretmen B “Kazanımlar çok fazla bu yüzden süre yetersiz kalıyor. Kazanımların hepsi kullanılmıyor ama yine de fazla. Elbette ki bu uygulamaların bazılarının çocukların söz varlığını 
geliştirmede olumlu katkıları vardır." şeklinde görüşünü ifade etmiştir. Benzer şekilde kimi öğretmenler kazanım sayısının fazlalı̆̆ına vurgu yapmıştır.
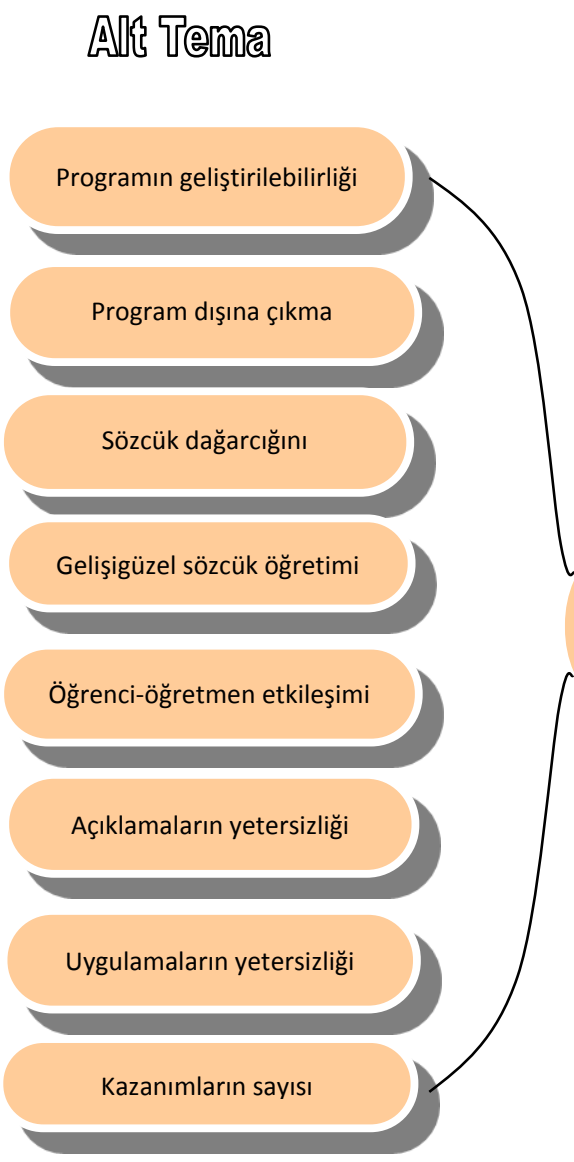

\section{『อณลa}

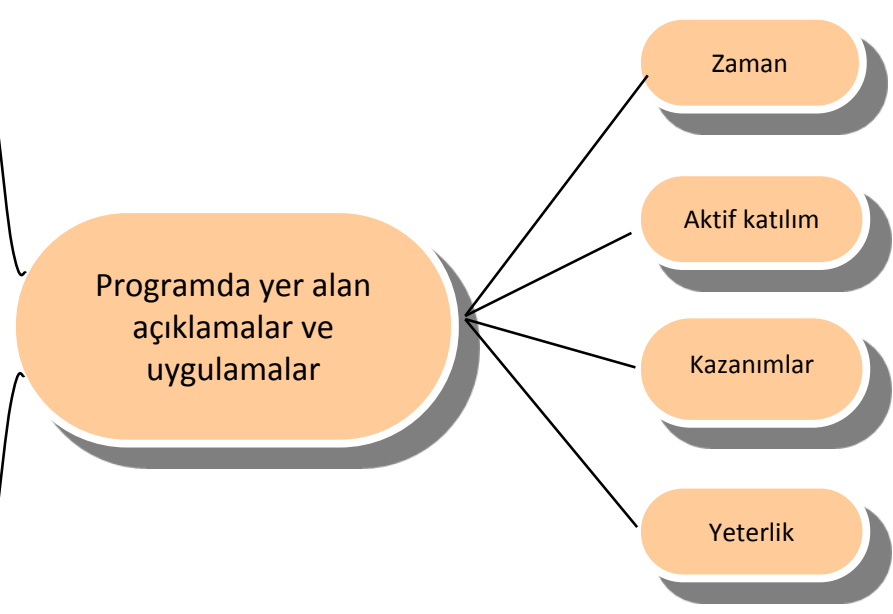

Şekil 1. Programda Yer Alan Açıklamalar ve Uygulamalara ilişkin Görüşler.

\section{Metin işleme basamaklarının yeterliliği}

Araştırma kapsamında öğretmenlerden alınan görüşler doğrultusunda sınıf öğretmenlerinin metin işleme basamaklarının sözcük öğretimi boyutunda yeterliliğiyle ilgili farklı görüş belirttikleri görülmektedir. Söz konusu ana temanın alt temaları ve kavramları ise Şekil 2'de verilmiştir.

Şekil 2'de metin işleme basamaklarının yeterliliği teması altında yer alan alt temalar ve kavramlar verilmiştir. Buna göre öğretmenlerden bir kısmı metin işleme basamaklarında yer alan etkinliklerin niteliğini sözcük öğretimi için uygun ve yeterli görürken öğretmenlerin bir kısmı ise etkinliklerin söz varlığı gelişiminde yetersiz olduğu görüşündedirler. Söz konusu görüşlere ilişkin olarak Öğretmen $A$, "Metin işleme basamaklarında gerçekleştirilen uygulamaları yeterli buluyorum. Anahtar kelimelerle merak içinde olmaları ve bilinmeyen kelimelerle merak gidermeleri sözcük gelişimine katkıda bulunuyor." şeklinde olumlu görüş sunarken Öğretmen K "Metin işleme basamaklarında yeni sözcük kullanımı ile ilgili olan etkinlikleri yeterli bulmuyorum" söylemi ile olumsuz görüş belirtmiş̧ir. Metin işleme basamaklarının gerçekleştirildiği etkinliklerin niteliği ile ilgili olarak bir diğer olumsuz öğretmen görüşü de etkinliklerdeki sözcüklerin öğrenci seviyesinin üzerinde olduğuna yöneliktir. Bu nedenle de öğretmenler etkinliklerin söz varlığı gelişimine katkı sağlamadığını düşünmektedirler. Sözcük öğretimi 
sürecinde metin işleme basamaklarında yer alacak etkinliklerin öğrencilerin ilgi ve beklentilerine göre düzenlenmesi ve anlaşılır uygulamalara yer verilmesi gerektiği öğretmenler tarafından vurgulanmaktadır.

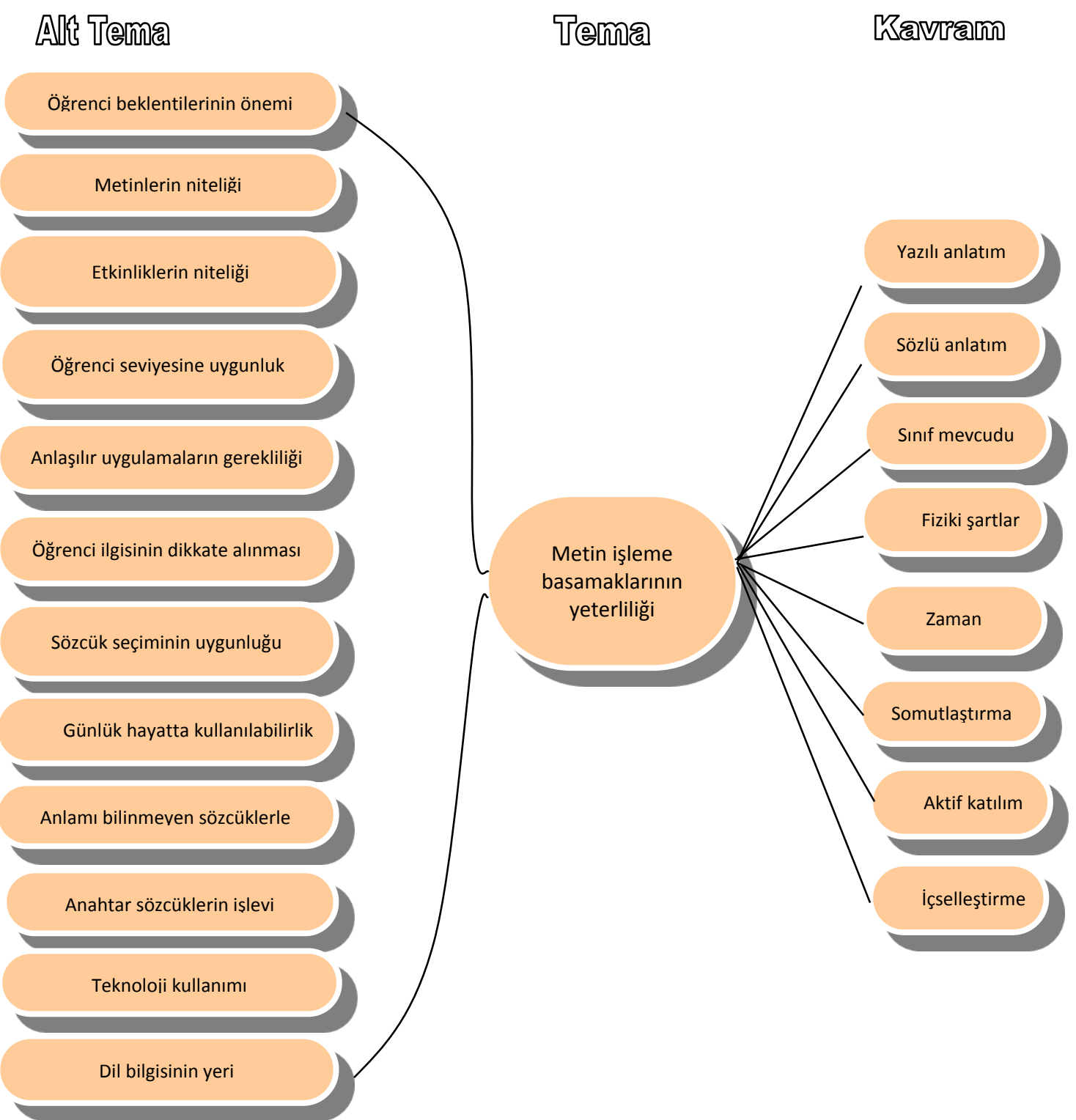

Şekil 2. Metin Işleme Basamaklarının Yeterliliğine iliş̧kin Öğretmen Görüşleri.

Öğretmenler Türkçe derslerinde işlenecek olan metinlerin niteliği ile ilgili olarak metinlerde yer alan sözcüklerin öğrenci seviyesine uygun ve anlaşılabilir olması gerektiğini ifade etmişlerdir. Bu konuyla ilgili olarak Öğretmen J, "Metin işleme basamaklarında gerçekleştirilen uygulamalar en azından benim öğrencilerimin sosyo ekonomik durumuna çok uygun değildir. Zaten kitaplarda yer alan metinler öğrencilerimize hitap etmemektedir." şeklinde görüşünü ifade etmiştir. Metinlerde sözcük türlerinin seçimine ilişkin olarak öğrencilerin kavramakta zorlandıkları soyut ve terim anlamlı sözcük yoğunluğunu gündeme getiren öğretmenler, metinlerde ve metin işleme basamaklarında gerçekleştirilen 
uygulamalardaki sözcük seçiminde de öğrencilerin yalnızca anlamını bilmedikleri sözcüklere yer vermenin sözcük dağarcığına katkı sağlamayacağını, anlamı bilinen sözcüklerin de günlük yaşantıda kullanılabilmesi için gerekli pekiştirmelerin yapılması gerektiğini ifade etmişlerdir. Bu konuyla ilgili olarak Öğretmen H, "Sadece anlamı bilinmeyen kelimelerle değil, anlamı bilinen belki de öğrencinin teneffüslerde bile ağızlarından düşürmediği kelimelerle de çalışılmalı kitaplarda. Çünkü söz varlığını geliştirmek anlamı bilinmeyen kelimelerin anlamını öğrenmek değildir. Çocuk bildiği ve bilmediği ne kadar çok kelimeyi konuşabilirse söz varlığı o kadar çok gelişir." şeklinde görüşünü ifade etmiştir. Benzer şekilde Öğretmen E, "Verilen kelimelerin sayısı arttırılmalıdır. Hiç duyulmayanlar değil, zaten bildiği tahmin edilen kelimelerin de hatırlatmak amacıyla verilmesi gerekir." şeklinde açıklamada bulunmuştur.

Elde edilen bulgular, öğretmenlerin, anahtar kelimelerle çalışmanın öğrencilerin sözcük dağarcığı gelişimine katkı sağlayacağı görüşünde olduklarını göstermektedir. Genel olarak metin işleme basamaklarının sözcük öğretiminde işlevsel olduğu görüşünde olan öğretmenler, yer alan uygulamalarda teknolojinin kullanımına daha çok önem verilmesi gerektiğini vurgulamışlardır. Sınıf mevcudunun, öğrenme ortamı fiziki koşullarının, zamanın ve öğrenci aktif katılımının metin işleme basamaklarının uygulamaya geçirilmesinde etkili olduğunu belirten öğretmenler; yazılı ya da sözlü anlatım yollarıyla sözcüklerin somutlaştırılması ve öğrenciler tarafından içselleştirilmesinin sağlanabileceğini ifade etmişlerdir. Ayrıca öğretmenlerin bazıları metin işleme basamakları etkinliklerinde dil bilgisine ağırlık verilmediği ve etkinliklerin yetersiz olduğu yönünde görüş belirtmişlerdir.

\section{Yöntem ve teknikler}

Araştırma kapsamında öğretmenlerden alınan görüşler doğrultusunda sözcük öğretim yöntem ve tekniklerine değindikleri görülmüştür. Söz konusu ana temanın alt temaları ve kavramları ise Şekil 3’de verilmiştir.

Şekil 3'te de görüldüğü gibi öğretmenler kendi öğrenme-öğretme süreçlerine özgü sözcük öğretim yöntem ve tekniklerine yer vermektedirler. Öğretmenler Türkçe dersi öğretme öğrenme sürecinde sözcük öğretimine yönelik olarak yakından uzağa ilkesine göre hareket ettiklerini, birçok duyu organını sürece kattıklarını, yeni öğrenilen sözcüklerin günlük hayatla ilişkilendirilebilmesine yönelik uygulamalara yer verdiklerini ve sürecin diğer dersler ile ilişkilendirilmeye çalışıldığını belirtmişlerdir. Çocuğun dünyasına girebilecek etkinlikler oluşturmanın önemini vurgulayan öğretmenler, yeni sözcüklerin öğrenciler tarafından kavranmasına yönelik olarak yeni sözcüklerin diğerleriyle ilişkilendirilmesi etkinliklerine yer verdiklerini, yeni sözcüklerin cümle içinde kullanıldığı ve sözcüklerin tekrarlarının yapıldığını ifade etmişlerdir. Bu konuyla ilgili olarak Öğretmen B "Öğrendiği yeni kelimeleri konuşmalarında kullandırmaya çalışıyorum. Yazılarında da kullanmaları için çalışıyoruz." şeklinde açıklamada bulunmuştur. Öğretmen I ise " Metni sessiz olarak okuturken anlamını bilmedikleri kelimeleri belirlemelerini ve altlarını çizmelerini söylüyorum. Daha sonra bu kelimelerin anlamını tahmin etmelerini sağlıyorum. Seviyelerine uygun sözlük kullanarak gerçek tanımlarını okutup yazdırıyorum. Yeni öğrenilen bu sözcükleri tanımladıktan sonra cümle içinde kullanıyor ve cümleyi de yazıyoruz. Yeni sözcüklerin öğreniminde yaparak yaşayarak öğrenme, canlandırma ve beyin fırtınası tekniklerini kullanıyorum." şeklinde görüşünü belirtmiştir.

Öğretmenlerden kimisi, süreç içerisinde yapılması gereken uygulamaların gerçekleştirilmesi bittikten sonra, öğrencilerin yeni sözcüklerin anlamlarını anladıklarını varsaydıklarını belirtmiştir. Sözcük öğretiminde yeni sözcüklerin öğrencilere kavratılabilmesi sürecinde zaman zaman sıkıntı yaşadıklarını belirten öğretmenler, bu sorunları aşmada sıklıkla meslektaşlarından destek aldıklarını belirtmişlerdir. Öğrencilerin üst düzey düşünme becerilerinin geliştirilebilmesi için zengin söz varlığına sahip olmalarının gerektiğini düşünen öğretmenler, öğrencilerin söz varlıklarını zenginleştirilebilmesi için de öğretmen, öğrenci, veli işbirliğinin şart olduğunu ifade etmişlerdir. 


\section{ANf Tema}

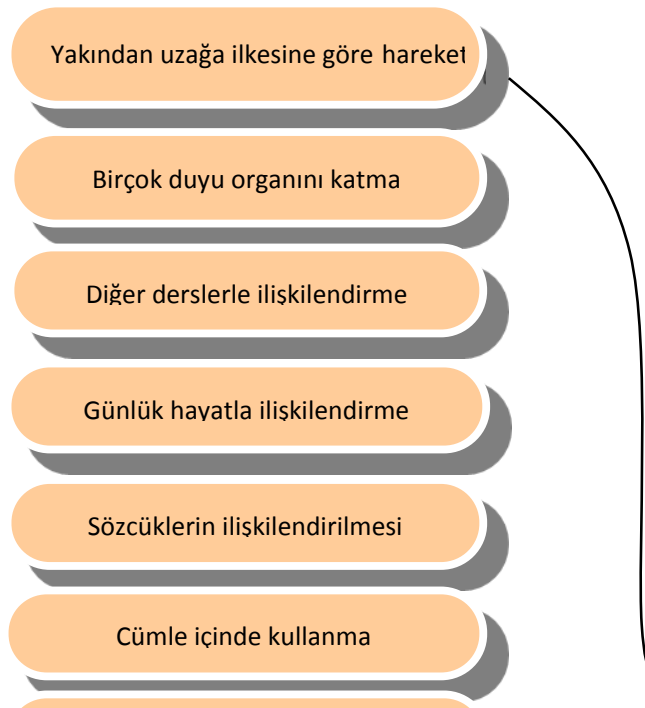

\section{Sık kullanarak assinalık olusturma}

Çocuğun dünyasına özgü etkinlikler

Anladığını varsavma

Meslektaşlara danışma

Öğrencilerin üst düzey becerilerini

Öğretmen-öğrenci-veli işbirliği

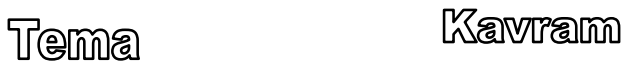

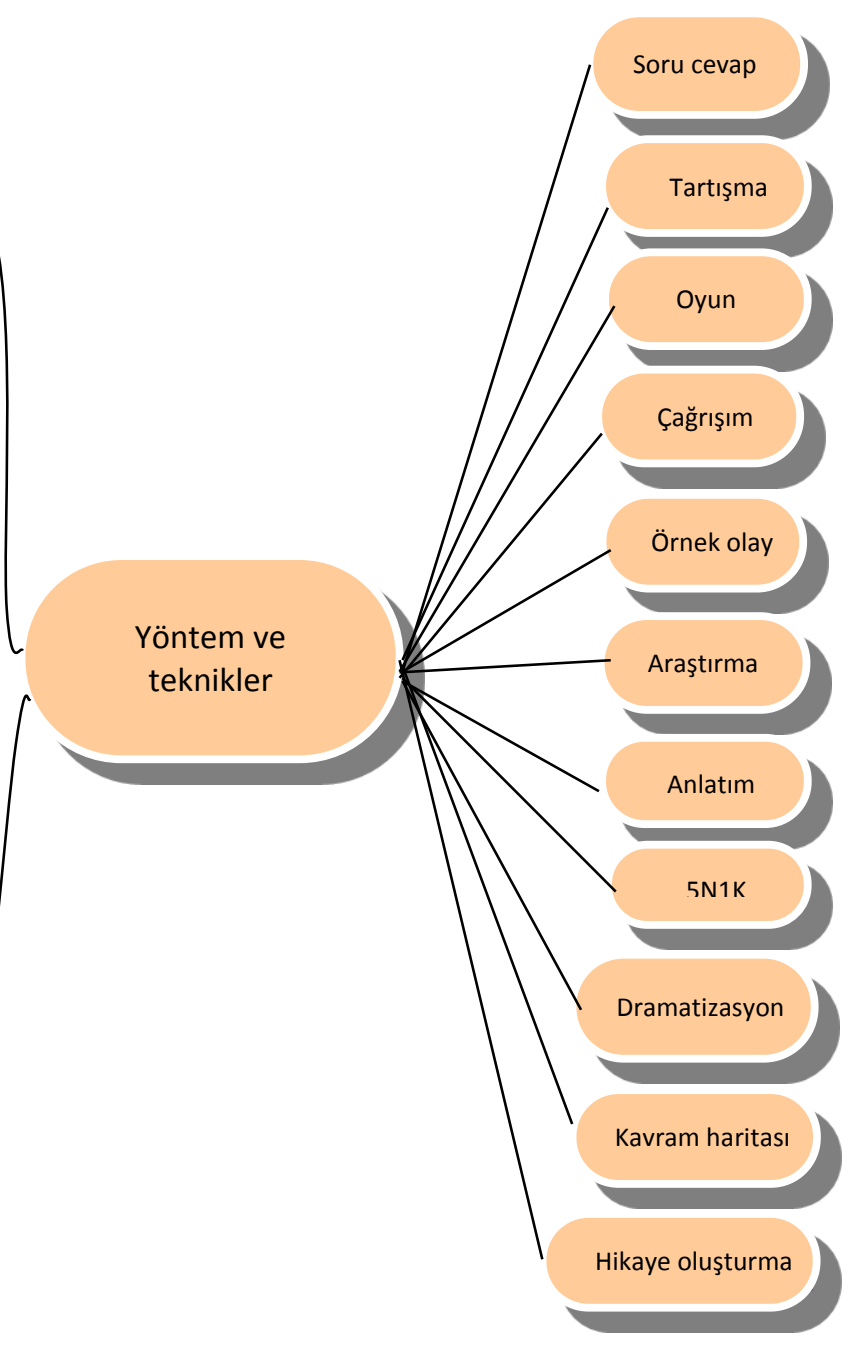

Şekil 3. Yöntem ve Tekniklere ilişkin Öğretmen Görüşleri.

Öğretmenler Türkçe derslerinde sözcük öğretimi sürecinde soru cevap, tartışma, oyun, çağrışım, örnek olay, araştırma, anlatım, dramatizasyon, kavram haritaları, 5N1K, hikaye oluşturma, bulmaca, ipucu verme, sezdirme, betimleme, beyin fırtınası, deneme yanılma, yaparak yaşayarak öğrenme, örneklendirme, somutlaştırma gibi yöntem ve tekniklere yer verdiklerini söylemişlerdir.

\section{Ders kaynaklarının kullanımı}

Araştırma kapsamında öğretmenlerden alınan görüşler doğrultusunda ders kaynaklarının kullanımı ana teması ortaya çıkmıştır. Söz konusu ana temanın alt temaları ve kavramları ise şekil 4'de verilmiştir.

Şekil 4'de öğretmenlerin sözcük öğretimine ilişkin çeşitli materyalleri kullandıkları görülmektedir. Öğretmenlerin sözlük, imla kılavuzu, deyimler ve atasözleri sözlüğü, sözcük görselleri, kaynak kitaplar, 
kısa öyküler, sözcük kartları, öğrencilerin sahip olduğu hikâye defterleri, öğrenci çalışma kitapları, ders kitapları, metinler, üç boyutlu materyaller gibi materyallerin sözcük öğretiminde yararlı olduğu konusunda hem fikir oldukları anlaşılmaktadır.

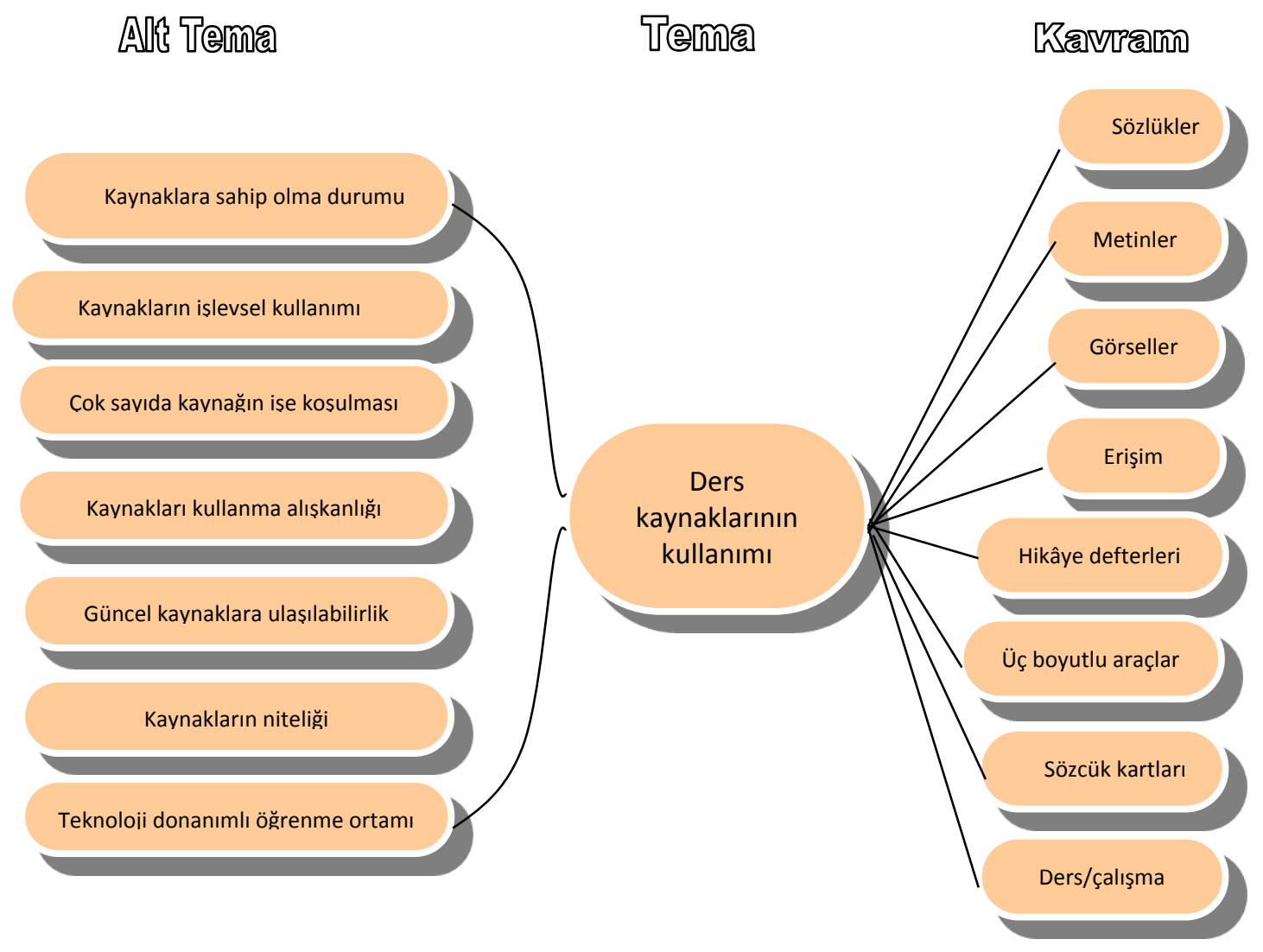

Şekil 4. Ders Kaynaklarının Kullanımına Yönelik Öğretmen Görüşleri.

Bu görüşü destekler ifadelerden birini Öğretmen $M$ şu şekilde ifade etmiştir: "Materyaller ile metinler desteklendiğinde söz varlığı gelişimine katkıda bulunacağını düşünmekteyim. Ancak bu materyaller aktif olarak kullanılmalı ve öğrencilere bu materyalleri kullanma alışkanlığı kazandııılmalıdır." Görüşle benzer şekilde söz konusu kaynakların sözcük öğretiminde öğrencinin aktif olmasını sağladığııı belirten öğretmenler, öğrencilerin söz konusu materyalleri kullanmaları konusunda ise öğrencilerin bazılarının materyallere sahip olamadığı, özellikle kırsal bölgelerde yaşayan öğrencilerin güncel kaynaklara ulaşılabilirlik konusunda sıkıntı yaşadığı görüşünü ifade etmişlerdir. Bu bağlamda Öğretmen L "Materyallerin çoğu elimizde yok, olanlar kullanmayı bilmiyor ve bu kaynaklar güncellenmeli." şeklinde yaşanılan sıkıntıyı dile getirmiştir. Öğretmenler sözcük öğretiminde yararlanılacak materyallere sahip öğrencilerin ise materyalleri kullanma alışkanlıklarının bulunmadığı, kimi zaman araçları yerinde ve doğru kullanamadıklarına yönelik eleştirilerde bulunmuşlardır. Bu konuyla ilgili olarak Öğretmen E "Kullanılan materyaller oldukça yeterlidir. Ama öğrenci bunları yük olarak gördüğünden yanlarında taşımamaktadırlar." şeklinde görüşünü ifade etmiştir.

Öğretmenler, sözcük öğretiminde de etkin olarak kullanılan ders kitaplarında yer alan metinlerin niteliğine yönelik sorunlar olduğu görüşündedirler. Ders kitaplarında yer alacak metinlerin öğrenci seviyesine uygun, görsel olarak desteklenmiş, öğrencilerin dikkatini çekici, merak uyandırıcı, öğrencileri 
araştırmaya sevk edecek özelliklere sahip olması gerektiğini vurgulayan öğretmenler, metinlerde yer alacak sözcüklerin öğrencilerin gelişim özellikleri dikkate alınarak soyut sözcüklerin yoğunluğundan ziyade somut sözcüklerden oluşması gerektiğini ifade etmişlerdir.

Öğretmenler ders kitaplarındaki metinlerin niteliğinin yanı sıra, öğrenci çalışma kitaplarındaki etkinliklerin niteliğiyle ilgili de çeşitli sorunlar yaşadıklarını gündeme getirmişlerdir. Söz konusu durumla ilgili olarak Öğretmen $D$ "1. sınıf öğrencilerinin yaptıkları Türkçe etkinlikleriyle, 4. sınıf öğrencilerinin yaptıkları etkinlikler arasında hiçbir fark yok. Burada biraz düşünülmesi gerekiyor bence. 1. sınıf öğrencisi ile 4. sınıf öğrencisinin ilgi ve öğrenme kapasitesi bir değildir sanırım." şeklinde görüşünü ifade ederken Öğretmen $F$ "Etkinlikler genelde, çalışma kitabındaki bilinmeyen sözcükler ve sözcükleri kullanma ile sınırlı kalıyor." şeklinde görüşünü açıklamıştır.

Öğretmenler sözcük öğretimi sürecinde teknolojik bakımdan donanık öğrenme ortamına sahip olmanın önemini vurgulayarak çok sayıda materyalin işe koşulmasının etkili sözcük öğretimi süreci geçirmeye yarar sağlayacağını ifade etmişlerdir.

\section{Kitle iletişim araçları}

Yapılan görüşmelerde öğretmenler, sözcük öğretiminin yalnızca sınıf içinde gerçekleşmediğini, öğrencilerin kitle iletişim araçlarından da yeni sözcükler öğrendiklerini belirtmişlerdir. Söz konusu ana temanın alt temaları ve kavramları ise Şekil 5 'te verilmiştir.

An? Tema

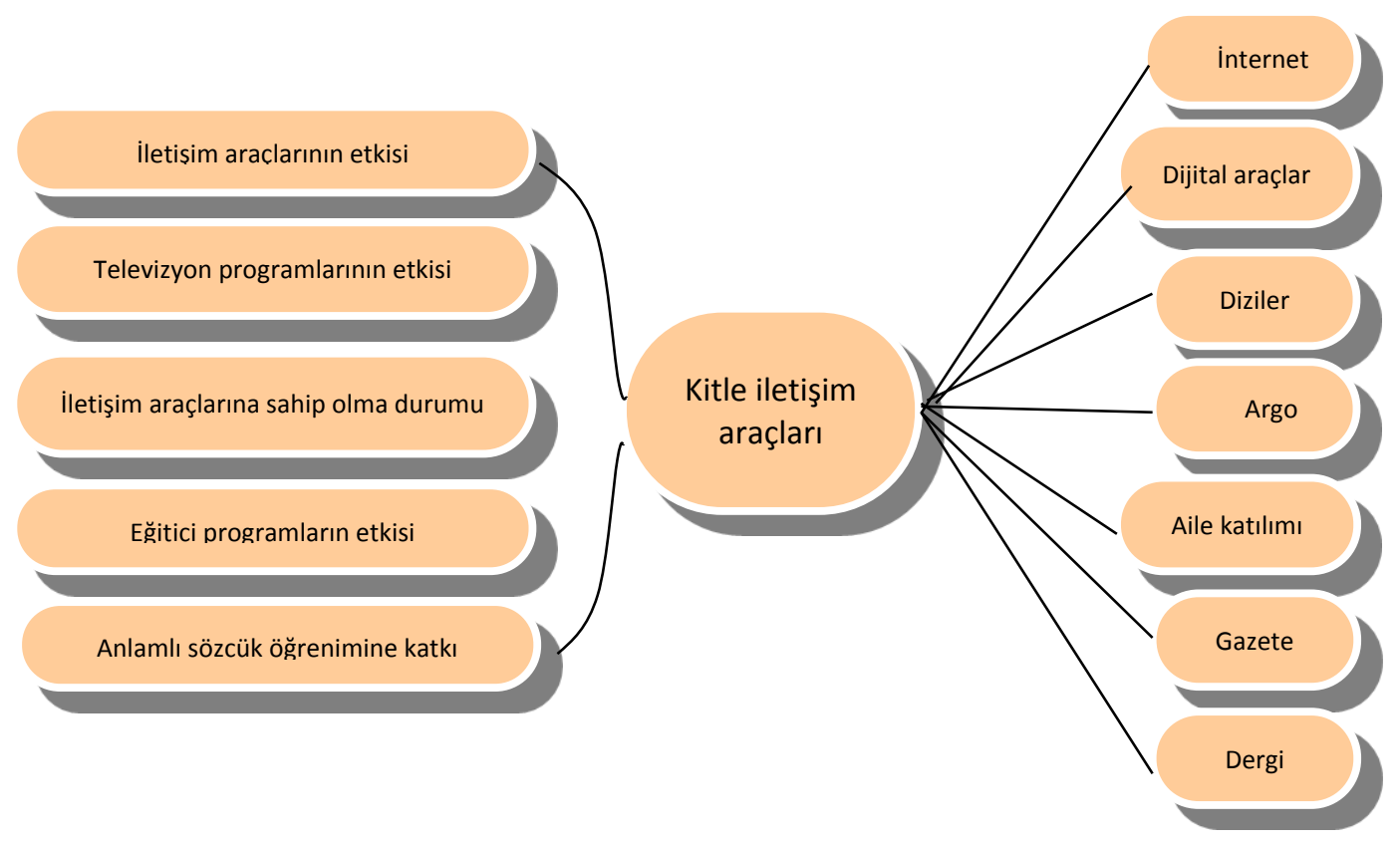

Şekil 5. Kitle Iletişim Araçlarına Yönelik Öğretmen Görüşleri.

Kitle iletişim araçlarının sözcük öğrenmeye etkisine yönelik öğretmen görüşleri Şekil 5'te verilmiştir. Kitle iletişim araçlarının olumlu ve olumsuz etkilerine değinen öğretmenler, daha çok uyarana maruz 
kalan öğrencilerin sözcük kullanımında daha başarılı olduklarını belirterek söz konusu uyaranların doğru ve yerinde kullanılması gerektiğini vurgulamışlardır. Bu konuyla ilgili olarak Öğretmen D “ Dağda yaşamış ve hiçbir uyarıcıya maruz kalmamış bir çocukla, birçok uyarıcıya maruz kalmış şehirdeki bir çocuk arasında çok fark olduğunu düşünüyorum." şeklinde düşüncesini ifade etmiştir.

Kitle iletişim araçlarından en yaygın olarak kullanılanlarından biri olan televizyonun sözcük öğretiminde olumsuz etkisinden bahseden öğretmenler, özellikle televizyon programlarında yer alan sözcüklerin anlamlı öğrenmeye katkı getirmediğini belirterek öğrencilerin birçok anlamsız sözcüğü kullanmaya başladıklarını ifade etmişlerdir. Eğitici nitelik taşıyan televizyon programlarının sözcük öğretiminde daha etkili olduğunu belirten öğretmenler, televizyon dizilerinde kullanılan argo sözcüklerin ise öğrencilerin sözcük gelişimini olumsuz etkilediğini vurgulamışlardır. Bu konuyla ilgili olarak Öğretmen B "Kitle iletişim araçları öğrencilerin yeni sözcük kazanımında etkileri çok fazla fakat olumsuz yönde etkisi var. Olumlu etkisi çok az..." şeklinde görüşünü belirtmiştir. Benzer şekilde Öğretmen E "iletişim araçları özellikle diziler olumsuz etkilemektedir." şeklinde görüşünü ifade etmiştir.

Öğretmenler, çağın gerektirdiği teknolojinin yakalanamadığı bölgelerde sadece sınıf içerisinde gerçekleştirilmek zorunda kalınan sözcük öğretiminin yetersiz olduğu görüşündedirler. İnterneti, eğitim CD’leri gibi dijital materyalleri, gazete ve dergileri sözcük öğretiminde yararlı gördüklerini ifade eden öğretmenler, ailelerin sosyo-ekonomik durumlarının bunları erişime doğrudan etkilediğini belirtmişlerdir.

\section{Çevre, aile etkisi}

Öğretmenlere göre sözcük öğretiminde etkili olan bir diğer faktör de öğrencilerin içinde yaşadığı çevre ve aileleridir. Söz konusu ana temanın alt temaları ve kavramları Şekil 6'da verilmiştir.

QASTema

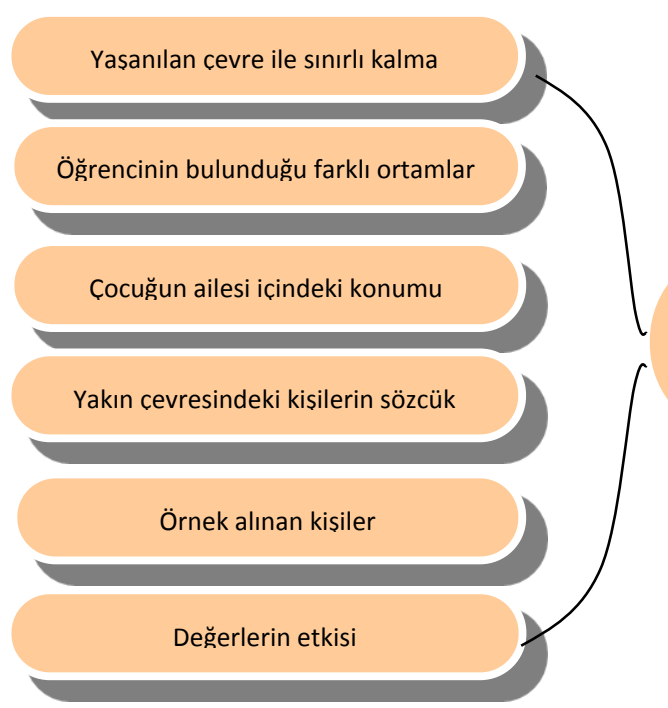

†ema

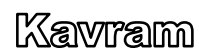

Şekil 6. Çevre-Aile Etkisine Yönelik Öğretmen Görüşleri.

Öğrencilerin yeni sözcükler öğrenmelerinde çevrelerindeki milli, manevi ve kültürel değerlerin de etkili olduğunu ifade eden öğretmenler, öğrencilerin okul yaşantısında öğrendikleri kimi sözcükleri ise günlük yaşantıya geçirmede sıkıntı yaşadıklarını belirtmişlerdir. Öğretmenler sosyo-ekonomik ve sosyo- 
kültürel faktörlerin öğrencilerin çevrelerini şekillendirdiğini, söz konusu faktörlere dayalı olarak da öğrencilerin yaşantılarının ve yaşam biçimlerinin çeşitlendiğini ifade etmişlerdir. Bu bağlamda sözü geçen faktörlerin sözcük öğrenmede etkili olduğunu vurgulayan öğretmenler, aile katılımının önemli olduğu görüşündedirler.

\section{Sonuç, Tartışma ve Öneriler}

Türkçe öğretim programı içerisinde yer alan sözcük öğretim sürecine ilişkin öğretmen görüşlerini belirlemek amacıyla yapılan bu çalışmada, öğretmenlerin Türkçe öğretim programının sözcük öğretimine yönelik açıklama ve uygulamalarının yeterliliğine ilişkin farklı görüşlere sahip oldukları görülmektedir. Öğretmenler sözcük öğretiminde, kendi öğrenme-öğretme süreçlerine özgü farklı uygulamalar gerçekleştirmektedirler. Bu sonuç Karadüz ve Yıldııı'ın (2011) araştırma sonucuyla da örtüşmektedir.

Elde edilen sonuçlardan bir diğeri ise öğretmenlerin Türkçe öğretim programında sözcük öğretimine ilişkin kazanımların sayısının fazla olduğuna yönelik görüşleridir. Oysa İlköğretim Türkçe Dersi (1-5. sınıflar) Öğretim Programında "söz varlığını geliştirme" alt başlığıyla "okuma" öğrenme alanında söz varlığını geliştirmeye yönelik yedi kazanım olduğu görülmektedir (MEB, 2005). Türkçe öğretim programında toplamda 1. sınıfta 132 kazanım, 2. sınıfta 172 kazanım, 3. sınıfta 210 kazanım ve 4. sınıfta 250 kazanım bulunmaktadır. Ancak bu kazanımlardan 1. Sınıfta 3'ü, 2. sınıfta 4'ü, 3. sınıfta 5'i, 4 . ve 5. sınıfta ise 6 'sı söz varlı̆ını geliştirme kazanımıdır. Bu bağlamda sözcük öğretimine ilişkin kazanım sayısı Türkçe öğretim programında yer alan diğer kazanımların sayısı ile karşılaştııılığında, sözcük öğretimine ilişkin çok az sayıda bir kazanımdan söz edilebilir. Bu nedenle öğretmenlerin sözcük öğretimine ilişkin kazanım sayısının fazla olduğuna yönelik görüşleri Türkçe öğretim programında sözcük öğretimine ilişkin yer alan kazanım sayısıyla ilgili bilgi sahibi olmadıkları şeklinde yorumlanabilir.

Öğretmenlerden bir kısmı metin işleme basamaklarında yer alan etkinliklerin niteliğini sözcük öğretimi için uygun ve yeterli görürken öğretmenlerin bir kısmı ise etkinliklerin söz varlığı gelişiminde yetersiz olduğu ve gerçekleştirilen etkinliklerdeki ve okuma metinlerindeki sözcüklerin öğrenci seviyesinin üzerinde olduğunu düşünmektedirler. Elde edilen bu sonuç Karadüz ve Yıldırım'ın (2011) araştırma sonuçlarıyla benzerlik göstermektedir. Benzer şekilde Bilgen, (Akt: Karatay, 2007) tarafından yapılan araştırmada da olmaması gereken bazı sözcüklerin ders kitaplarında yer aldığı, olması gerektiği düşünülen sözcüklerin ise olmadığı belirtilmektedir.

Öğretmenler anahtar sözcüklerle çalışmanın öğrencilerin sözcük dağarcığı gelişimine katkı sağlayacağı görüşündedirler. Ayrıca öğretmenler metin işleme basamaklarında gerçekleştirilen uygulamalardaki sözcük seçiminde de öğrencilerin yalnızca anlamın bilmedikleri sözcüklere yer vermenin sözcük dağarcığına katkı sağlamayacağını, bunun yanında anlamı bilinen sözcüklerin de günlük yaşantıda etkin kullanılabilmesi için gerekli pekiştirmelerin yapılması gerektiğini düşünmektedirler. Benzer şekilde Başdamar (2010) Türkçe ders kitaplarında yapılan etkinliklerin öğrencilerin sözcük dağarcığını geliştirme konusunda yeterli ve etkili olmadığını belirterek sözcük dağarcığı gelişimi için ayrılmış bir ders saati olmasının gerektiği yönünde öneride bulunmaktadır.

Öğretmenler, yeni öğrenilen sözcüklerin öğrenciler tarafından içselleştirilmesinin sağlanabilmesi için bu sözcüklerin yazılı ve sözlü anlatım yoluyla somutlaştırılması gerektiği görüşündedirler. Ayrıca öğretmenlerin sözcük öğretiminde kendi öğrenme-öğretme süreçlerine özgü yöntem ve tekniklerine yer verdikleri görülmektedir. Öğretmenler Türkçe dersi öğretme öğrenme sürecinde sözcük öğretimine yönelik olarak yakından uzağa ilkesine göre hareket etmekte ve birçok duyu organını sürece katmaya çalışmaktadırlar. Öğretmenlerin ayrıca yeni öğrenilen sözcüklerin günlük hayatla ve diğer derslerle ilişkilendirilebilmesine yönelik uygulamalara yer verdikleri görülmektedir. Öğretmenlerin gerçekleştiklerini belirttikleri bu uygulamalar, sözcük öğretiminde kalıcı öğrenmeye yardımcı olacaktır (Gürses, 2003).

Öğretmenler sözcük öğretim sürecinde, yeni sözcüklerin diğerleriyle ilişkilendirilmesi, yeni sözcüklerin cümle içinde kullanılması ve sözcüklerin tekrarlarının yapılması gibi uygulamalara yer 
vermektedirler. Nitekim yeni öğrenilen sözcüklerin sık sık kullanılması ve kavranamayan sözcüklerin altını çizerek yanlarına sözlük anlamının yazılıp okunması, sözcük öğrenmede uygulanabilecek yöntemlerdir (Ruşen 1999).

Öğretmenlerin Türkçe dersi sözcük öğretimi sürecinde soru cevap, tartışma, oyun, çağrışım, örnek olay, araştırma, anlatım, dramatizasyon, kavram haritaları, 5N1K, hikaye oluşturma, bulmaca, ipucu verme, sezdirme, betimleme, beyin fırtınası, deneme yanılma, yaparak yaşayarak öğrenme, ödüllendirme, somutlaştırma gibi yöntem ve teknikler kullandıkları görülmektedir. Çünkü öğretilmesi hedeflenen sözcükler ne kadar farklı etkinliklerle öğrencilere kavratılırsa öğrenme de o kadar kalıcı olacaktır (Gürdal ve Arslan, 2011, s. 36). Kaya ve Yapıcı (2007) da dil öğretiminde oyun ve bulmacaların dersi daha ilginç ve eğlenceli hale getirdiğini belirtmektedir. Benzer şekilde Çeçen (2007) ile Gürdal ve Arslan (2011) öğrencilerin söz varlıklarını geliştirmek için kelime oyunları, bulmacalar, bilmeceler vb. içeren etkinliklerden yararlanmanın önemini vurgulamışlardır.

Öğretmenlerin sözcük öğretiminde sözlük, imla kılavuzu, deyimler ve atasözleri sözlüğü, sözcük görselleri, kaynak kitaplar, kısa öyküler, sözcük kartları, öğrencilerin sahip olduğu hikâye defterleri, öğrenci çalışma kitapları, ders kitapları, metinler, üç boyutlu materyaller gibi materyallerin yararlı olduğu görüşündedirler. Nitekim birtakım araştırmalar sözcük öğretiminde sözlüklerden yararlanmanın önemli olduğunu vurgulamaktadır (Çeçen, 2007; Göçer, 2009; Karatay, 2007; Gürses, 2003). Ancak öğretmenlerin sözcük öğretiminde yararlanılacak materyallere sahip öğrencilerin bu materyalleri kullanma alışkanlıklarının bulunmadığı, kimi zaman araçları doğru ve yerinde kullanamadıklarına yönelik eleştirileri vardır.

Öğretmenlerin yeni sözcüklerin öğretimi sürecinde zaman zaman sıkıntı yaşadıkları ve bunları aşmak için sıklıkla meslektaşlarından destek aldıkları görülmektedir. Söz konusu sonuç Karadüz ve Yıldırım'ın (2011) araştırma sonuçlarıyla da örtüşmektedir. Nitekim Karadüz ve Yıldırım (2011) da sözcük öğretiminde öğretmenlerin; öğrenciden, sözcüklerin yapısından, çevreden ve kaynak yetersizliğinden kaynaklanan birtakım güçlükler ve sorunlar yaşadıklarını saptamışlardır.

Öğrencilerin üst düzey düşünme becerilerinin geliştirilebilmesi için zengin söz varlı̆ı̆ı sahip olmalarının gerektiğini düşünen öğretmenler, öğrencilerin söz varlıklarının zenginleştirilebilmesi için de öğretmen, öğrenci ve veli işbirliğinin şart olduğunu düşünmektedirler.

Öğretmenler, sözcük öğretim sürecinde teknolojik bakımdan donanık öğrenme ortamına sahip olmanın ve çok sayıda materyalin işe koşulmasının etkin sözcük öğretimi açısından önemli olduğu görüşündedirler. Nitekim Kolich (1991; Akt: Baturay, Yıldırım ve Daloğlu, 2007) yaptı̆̆ı bir araştırmada öğrencilerin bilgisayarlardan sözcük öğrenmeyi oldukça zevkli ve verimli bulduklarını ortaya koymuş ancak bu teknolojinin tek başına kullanılmayıp öğretmen kontrollü etkinlikler ile desteklenmesi gerektiğini savunmuştur. Benzer şekilde Karatay (2007), teknolojik gelişmeler ışığında, öğrencilerin söz varlığını geliştirmeye çalışmanın öğrenmeyi de eğlenceli hale getirebileceğini ifade etmiştir.

Öğretmenler kitle iletişim araçlarının sözcük öğrenmede olumlu ve olumsuz etkilerine değinmişlerdir. Ayrıca sözcük öğretiminde öğrencilerin yaşadıkları çevre ve ailenin de etkili olduğu görüşündedirler. Demir (2007) de çocuklarının sözcük dağarcığııı gelişmesi ve zenginleşmesinin ailenin yardımına bağlı olduğu düşüncesindedir.

Öğrencilerin yeni sözcükler öğrenmelerinde çevrelerindeki milli, manevi ve kültürel değerlerin de etkili olduğunu ifade eden öğretmenler, öğrencilerin okul yaşantısında öğrendikleri kimi sözcükleri ise günlük yaşantıya geçirmede sıkıntı yaşadıklarını belirtmişlerdir. Öğretmenler sosyo-ekonomik ve sosyokültürel faktörlerin öğrencilerin çevrelerini şekillendirdiğini, söz konusu faktörlere dayalı olarak da öğrencilerin yaşantılarının ve yaşam biçimlerinin çeşitlendiğini ifade etmişlerdir. Yapılan birtakım araştırmalar, sosyo-ekonomik düzeyin yüksek ya da düşük olmasının söz varlığının niteliğini doğrudan etkilediğini göstermektedir (Hart ve Risley, 1995; Öztürk, 1995). Öte yandan Slobin (1979; Akt: Bilgin ve İpek, 2007) de çevre uyaranlarından yoksun ortamlarda yetişen çocukların dil düzeylerinin düşük olmasını, çevrenin dil gelişimi üzerindeki etkisi ile açıklamaktadır. 
Elde edilen sonuçlar doğrultusunda ise şu öneriler geliştirilebilir:

- Bu araştırmanın benzeri daha geniş bir çalışma grubu üzerinde gerçekleştirilebilir.

- Sözcük öğretiminde kullanılan metin ve metin etkinliklerinin niteliği üzerine çalışmalar yapılmalıdır.

- Sözcük öğretimi etkinlik ve metinlerinde yalnızca yeni sözcük öğretiminden daha çok önceden öğrenilen sözcüklerin pekiştirilmesine ya da kullanımına yönelik çalışmalara da yer verilmelidir.

- Sözcük öğretiminde güncel teknolojiden işlevsel olarak yararlanılmalıdır.

- Öğrencilerin söz varlığııın geliştirilebilmesinde öğretmen-öğrenci ve veli işbirliği dikkate alınmalıdır.

\section{Kaynakça}

Ağca, H. (1999). Yazılı anlatım. Ankara: Gündüz Eğitim ve Yayıncılık.

Akarsu, B. (1998). Wilhelm Von Humbold'da dil-kültür bağlantısı. İstanbul: İnkılap Kitabevi.

Aytaş, G. (2001). Türkçe ders kitaplarının yazımında metin seçimi ve metin altı sorularının hazırlanmasında dikkat edilmesi gereken bazı hususlar. Türk Yurdu (Türkçeye Saygı Özel Sayısı), 21, 162-163.

Baturay, M. H., Yıldırım, i.S. \& Daloğlu, A. (2007). Web-tabanlı kelime öğretimi ve tekrar modeli. Politeknik Dergisi, 10 (3), 241-245.

Başdamar, G. (2010). Yazılı çalışmalar yaptırılarak öğrencilerin kelime dağarcığını zenginleştirme uygulamaları, etkinlikleri ve ölçme değerlendirmeleri. Unpublished master's thesis, Erzincan Üniversitesi, Erzincan.

Bilgin, A. \& Ipek, N. (2007). illköğretim çağı çocuklarında kelime dağarcığı gelişimi. ilköğretim Online, 6(3), 344-365.

Calp, M. (2010). Özel eğitim alanı olarak Türkşe öğretimi. Ankara: Nobel Yayın Dağıım.

Cresswell, J. (2012). Educational research. Boston: Pearson Education Inc.

Cunningham, A. E. \& Stanowich, K. (1998). What reading does to the mind. American Educator, 22 (1), 8-15.

Çeçen, A. (2002). ilköğretim öğrencilerinde kelime hazinesinin geliştirilmesi. Unpublished master's thesis. İnönü Üniversitesi, Malatya.

Çeçen, M. (2007). Kelime hazinesinin geliştirilmesinde dikkat edilmesi gereken hususlar. Journal of Turkish Linguistics, 1 (1), 116- 137.

Demir, C. (2007). Türkçe/edebiyat eğitimi ve kişisel kelime serveti. Milli Eğitim, 169, 207-225.

Demirel, Ö. (2006). Türkçe öğretimi. Ankara: PegemA Yayıncılık.

Ersoy, A. \& Yalçınoğlu, P. (2012). Nitel araştırmaya giriş. Ankara: Anı Yayıncılık.

Göçer, A. (2009). Türkçe eğitiminde öğrencilerin söz varlığını geliştirme etkinlikleri ve sözlük kullanımı. Turkish Studies, 4 (4), 1025-1055.

Göğüş, B. (1983). Anadili eğitim programlarının niteliği. Türk Dili, 379-380, 40-48.

Güneş, F. (2002). Ders kitaplarııın incelenmesi. Ankara: Ocak Yayıncılık.

Gürdal, A. \& Arslan, M. (2011). Oyun ve bulmaca etkinlikleriyle yabancılara Türkçe kelime öğretim yöntemi. 1. International Conference on Foreign Language Teaching and Applied Linguistics. Sarajevo May 5-7 2011.

Gürses, R. (2003). Kelime öğretimi üzerine bir genel değerlendirme, Türk Dili Dil ve Edebiyat Dergisi, 622, 506-516.

Hameau, M. (1988). Söz dağarcığı öğretimi (Trans: Ramis Dara). Uludağ Üniversitesi Eğitim Bilimleri Fakülteleri Dergisi, 3 (1), 301-305. 
Hart, B. \& Risley, R. T. (1995). Meaningful differences in the everyday experience of young American children. Baltimore: Paul H. Brookes.

Kaptı, Ü. (2008). Alman dili eğitiminde sözcük öğretimi amacıyla web sayfalarının kullanımı, VIIı. International Educational Technology Conference, Eskişehir: Anadolu Üniversitesi.

Karadüz, A. \& Yıldırım ì. (2011). Kelime hazinesinin geliştirilmesinde öğretmen görüş ve uygulamaları. Gaziantep Üniversitesi Sosyal Bilimler Dergisi, 10 (2), 961-984.

Karatay, H. (2007). Kelime öğretimi. Gazi Üniversitesi Gazi Eğitim Fakültesi Dergisi, 27 (1), 141-153.

Kaya, Z. (2002). Uzaktan eğitim. Ankara: PegemA Yayıncılık.

Kaya, Ü. Ü. (2007). Illköğretim 1. kademede oyun tekniğinin erişiye etkisi. Unpublished master thesis. Afyon Kocatepe Üniversitesi, Afyonkarahisar, Türkiye.

Kılıç, A. \& Seven S. (2002). Konu alanı ders kitabı incelemesi. Ankara: PegemA Yayıncılık.

MEB, (2009). Illköğretim Türkçe dersi öğretim programı ve kılavuzu (1-5. sınıflar). Ankara: Devlet Kitapları Müdürlüğü Basım Evi.

Miles, M. B., \& Huberman, A. M. (1994). An expanded sourcebook qualitative data analysis. Second Edition. California: Sage Publications, Inc.

Neuman, L.W. (2010). Toplumsal araştırma yöntemleri nitel ve nicel yaklaşımlar. İstanbul: Yayın Odası Yayıncılık.

Öztürk, H. (1995). Okul öncesi eğitim kurumlarına giden ve gitmeyen ilkokul birinci sınıf öğrencilerinin alıcı ve ifade edici dil düzeyleri. Unpublished master's thesis. Gazi Üniversitesi, Ankara, Türkiye.

Paul, V. P. (1996). Reading vocabulary knowledge and deafness. Journal of Deaf Studies and Deaf Education. 1 (1), 3-5.

Pehlivan, A. (2008). Türkçe kitaplarında sözcük dağarcı̆̆ını geliştirme sorunu ve çözüm yolları. TÖMER Dil Dergileri, 122, 84-94.

Ruşen, M. (1999). Hızlı okuma. İstanbul: Alfa Yayın.

Sağır, M. (2002). Illköğretim okullarında dil bilgisi öğretimi. Türk Dili, 601, 58.

Stemler, S. (2001). An overview of content analysis. Practical Assessment, Research \& Evaluation, 7 (17), 137-146.

Wolcott, H. F. (1990). On seeking-and rejecting-validity in qualitative research. E. W. Eisner, \& A. Peshkin içinde, Qualititative inquiry in education the coutinuing debate (pp.121-152). New York: Teachers Collage Press.

Yalçın, S. K. (2005). Illköğretim 1. ve 5. sınıf Türkçe ders kitaplarının söz varlığı açısından değerlendirilmesi. XIV. Ulusal Eğitim Bilimleri Kongresi. Denizli: Pamukkale Üniversitesi.

Yalçın, S. K. \& Özek, F. (2006). Söz varlığının temel dil becerilerinin ve akademik disiplinlerin kazanına olan etkileri. Milli Eğitim Dergisi, 171, 130-139.

Yıldırım, A. \& Şimşek, H. (2006). Sosyal bilimlerde nitel araştırma yöntemleri. Ankara: Seçkin Yayıncılık. 